\title{
'But the Dutch would call it exploitation'. Crimmigration and the moral economy of the Chinese catering industry in the Netherlands
}

\author{
Jing Hiah ${ }^{1} \cdot$ Richard Staring $^{1}$ (D)
}

Published online: 21 June 2016

(C) The Author(s) 2016. This article is published with open access at Springerlink.com

\begin{abstract}
Based on qualitative research into the Chinese catering industry in the Netherlands, this article describes labour relations between Chinese employers and their (undocumented) employees against the background of a society in which criminal, administrative, and immigration law increasingly converge. The authors argue that the intertwining of these three fields of law asks for an adaptation of the concept of crimmigration. Furthermore the authors claim that an overemphasis on the legal definition of 'labour exploitation' distances law from the people it addresses as it reduces employers to offenders and employees to victims. Such a normative perspective prevents us from gaining further insights into underlying issues such as illegal stay, informal labour practices and labour relations within migrant niches. The authors argue on the contrary that Chinese restaurant owners and their employees operate in a 'moral economy' where labour relations are influenced not only by formal rules and a demand for reasonably priced food and flexible, motivated, inexpensive and skilled employees, but also by informal rules and culturally shared expectations about justice and reciprocity.
\end{abstract}

Richard Staring

staring@law.eur.nl

Jing Hiah

hiah@law.eur.nl

1 Department of Criminology, Erasmus University Rotterdam, Burgemeester Oudlaan 50,

P.O. Box 1738, 3000 DR Rotterdam, the Netherlands 


\section{Troubles in the Dutch Chinese restaurants}

In early April, 2014, Chinese restaurant owners ${ }^{1}$, together with their employees, took to the Dutch streets to protest against the amendment of the Foreign Nationals Employment Act (WAV). ${ }^{2}$ Protesters carried banners with slogans such as 'no work permit $=$ no chop suey' and 'no Chinese cooks = no Chinese kitchens!'. Tightening this legislation would mean an end to the existing practice whereby cooks residing in China could be employed in the Netherlands with a work permit for a third country national (TCN). Amending the WAV would also make it impossible for owners of Chinese restaurants to extend the employment contracts of current employees who are employed by a work permit for a TCN. According to the Ministry of Social Affairs and Employment the employment of TCNs too often results in irregular migration and illegal work by undocumented immigrants that, in turn, leads to unfair competition on the Dutch labour market. $^{3}$ Owners of Chinese restaurants, however, were convinced that it would be impossible to recruit enough suitable employees from the existing employment pool ([6], p. 2). Tightening the WAV would threaten the existence of the Chinese restaurants affected if no fitting solution could be found. ${ }^{4}$ Ultimately, the Dutch government found a temporarily solution in formulating an exception to the amendment of the WAV for amongst others the Chinese restaurants, to continue the employment of qualified Asian cooks for a period of two years. Within this timeframe Chinese restaurant owners should have trained enough indigenous apprentice cooks from the Netherlands or other member states of the European Union in order to fulfil the demand for Chinese cooks for the nearby future. ${ }^{5}$

In this contribution we will analyse labour related issues within the Chinese Dutch catering industry from the perspective of Chinese entrepreneurs and their employees. What considerations do they have when it comes to issues raised above as employing undocumented Chinese immigrants? How do these Chinese entrepreneurs understand the current legal situation and how do they perceive the impact of possible labour inspection's administrative fines on their businesses? How do Chinese employers and employees perceive the working conditions in the restaurants and how do the Chinese relate these views to Dutch policies on illegal migrant labour and undocumented immigrants and legal norms regarding human trafficking in which exploitation is a core element [28]?

\footnotetext{
${ }^{1}$ The authors would like to thank the anonymous peer reviewers for their constructive and valuable comments.

${ }^{2}$ The amendment of the WAV was published in the Bulletin of Acts and Decrees (Stb 499) on 9 December 2013 and entered into effect as from 1 January 2014.

${ }^{3}$ For those immigrants who lack valid residence permits in order to stay in the Netherlands, we will employ the term 'undocumented immigrant'. As a rule, undocumented immigrants lack a valid work permit and carry out illegal labour; work that is in conflict with the WAV. We will refer to work carried out by undocumented immigrants as illegal migrant labour. Note that Dutch citizens can also work in the informal sector, if they are working outside the reach of governmental legislation and regulation, although they do not risk expulsion nor temporary imprisonment as the undocumented do ([52], p. 60).

${ }^{4}$ Also see the letter from the standing committee on Social Affairs and Employment to Minister Asscher, on 4 April 2014, reference number 153498.02u, <http://www.eerstekamer.nl/wetsvoorstel/33475_herziening_van_ de_wet_arbeid>

${ }^{5}$ See the letter of Minister Asscher of Social Affairs and Employment on October 1, 2014 to the chair of the Senate of the States General <https://www.eerstekamer.nl/behandeling/20141001/brief_van_de_minister_ van_szw_over/document3/f=/vjnoivllimxg.pdf $>$.
} 
By including the perspectives of Chinese immigrants and their ways of dealing with the requirements of the WAV we hope for a better understanding of how legal rules interact with and influence existing social practices within specific social fields [30]. The Chinese catering sector is relevant for its long history with the Dutch government trying to regulate Chinese immigration and entrepreneurship. Van Eijl [54] describes how more than a century ago the Dutch government started with categorizing Chinese as a special group of immigrants who were associated with 'illegality' and crime that had to be dealt with by custom-made measures in order to avoid negative economic and societal reactions (Ibid., p. 76-94). In addition, an analysis of the Chinese catering sector could also contribute to the broader academic debate on crimmigration. First of all by including the perspectives of the people who are subject to control and secondly by addressing how administrative law along criminal law is applied within this field with the purpose of controlling immigration.

\section{Chinese restaurants under administrative and criminal law}

The above mentioned adjustment of the Dutch Foreign Nationals Employment Act (WAV) restricts the entrance of foreign employees and aims at fighting illegal employment in order to prevent labour exploitation and human trafficking as well as unfair competition on the labour market. It is in the scope of illegal employment (article 197b of the Dutch Criminal Code) as well as human trafficking (article $273 \mathrm{f}$ of the Dutch Criminal Code) that criminal enforcement of the WAV becomes an option. Whilst the amendment of the WAV further restricts the entrance of foreign employees, article $273 \mathrm{f}$ of the Dutch Criminal Code on human trafficking together with new implemented measures on criminalizing illegal stay aim to exclude immigrants after arrival [49]. These developments in further regulating immigration through the use of criminal law fit in what has been described as the process of crimmigration. Crimmigration is defined as a process in which criminal law increasingly becomes important by means of controlling immigration which will lead to further social exclusion and increased vulnerability of undocumented immigrants $[1,50,53]$. Yet in the context of the employment of Chinese cooks in the Chinese restaurants, it is not only criminal law but also administrative law that merges with migration law in an effort to control migration.

Due to the dissatisfaction with the efficiency and the results of criminal procedures, the enforcement of the WAV has from 2005 onwards been gradually transferred from criminal law to administrative law. Currently, the enforcement of the prohibition on illegal employment takes primarily place through (intensified) controls and fines that lie predominantly within the domain of administrative law and not criminal law. Administrative fines, instead of criminal sanctions are being perceived as more effective and easier to implement. In the case of the WAV, the introduction of administrative law came along with tougher enforcement through increased inspections and higher administrative fines ([25], p. 131-133). Krop [25] criticizes the present definition of crimmigration of being too much USA-centred. Instead he argues that this definition of crimmigration should be widened as in the Dutch case the amendment of the WAV and the accompanying sanctioning of employers is an administrative measure, yet simultaneously deals with central crimmigration issues such as the fundamental rights of 
migrants as well as ad-hoc instrumentalisation of most effective measures in order to control migration.

\section{Human trafficking and the moral economy}

Human trafficking has been punishable at the international and European level since the adoption of the UN protocol to Prevent, Suppress and Punish Trafficking in Persons, especially Women and Children in 2000, also known as the Palermo protocol, by the European Parliament and Council in Directive 2011/ 36/EU. Human trafficking outside of the sex industry is defined as the recruitment, transportation, transfer, harbouring or reception of persons, with use of coercion (in the broadest sense) and for the purpose of exploitation. This definition and the concept of exploitation in particular, leaves room for interpretation and in the different implementation countries this task has been left to the judiciary $[16,44]$.

In the 'Chinese catering sector' case (2009) eight undocumented Chinese workers were found by the Dutch labour inspectorate employed under poor labour conditions in a Chinese restaurant. Yet neither the undocumented workers viewed themselves as victims nor the employer thought of himself as a perpetrator. Based on this case the Dutch Supreme Court formulated further criteria on how to assess human trafficking as labour exploitation, which are: the labour conditions of employment, the economic advantage for the employer and the constraints imposed on the immigrant workers. Constraints do not only refer to physical constraints, but also to (psychological) vulnerability and multiple dependency. Multiple dependency refers to what extent the worker has a choice in turning down the job and to what extent does the worker depend on the employer for other services next to employment? Based on previous jurisprudence (Dutch Supreme Court 5 February [14], NJ 2002/546) the constraints are argued to be intertwined with the legal status of undocumented immigrants as their lives are to a greater degree identified with vulnerability, multiple dependency and victimhood (See also [3, 4, 29]). To fulfil the criteria of human trafficking, the employment and resulting abuse need not necessarily be initiated by the employer and consent given by the employee does not mitigate the exploitation (Dutch Supreme Court 27 October [13], LJN BI7097). Unlike other countries, the essence of human trafficking law in the Netherlands is thus exploitation which as consequence means that borders do not have to be crossed to involve human trafficking [44].

'Culture' played a considerable role in the 'Chinese catering sector' case, as suspects and victims shared the same cultural background similar to many other human trafficking cases ([51]). Bogaerts et al. point to the significance of culture in the 'cultural defence', whereby suspects claim their cultural background as grounds for exemption from criminal liability or for a reduced sentence ([4], p. 264). The authors observe that judges are generally reluctant to take the cultural background of suspects into account, partly because an appeal to cultural relativism could stand at odds with the basic principle that human trafficking should be judged by Dutch standards (Ibid., p. 276). In the 'Chinese catering sector' case the solicitor-general at the court session stated the following about culture: 
'In Chinese culture there is always someone in charge, and this person must be obeyed. The employees have come to the Netherlands through human smuggling and will therefore find it difficult to return to their homeland. (...) In practice and I see this as a well-known fact of Chinese culture in the Netherlands - this means that a debt has been incurred. Sometimes by an individual, but much more often by the family back in China. The debt must be paid off and this puts enormous pressure on the victims to accept work, no matter the circumstances.' (Supreme Court 27 October [13], LJN BI7097)

In this quote, culture is depicted as a static entity, but there is no such thing as 'the Chinese culture' any more than there is something that can be called 'the Dutch culture'. Nor is it a given that every Chinese migrant who comes to the Netherlands with the help of a 'snakehead' is being forced to work to pay off his debts. ${ }^{6}$ Bogaerts et al. [4] correctly argue that if 'culture' is referred to during the trial, there is a danger that unfounded generalisations and stereotypes will influence the decisions being formed in the court room.

Finally, the 'Chinese catering sector' case also illustrates that labour and entrepreneurship do not take place in a social vacuum, but are embedded in social relations that are given shape and content in specific cultural or sub-cultural settings in interaction with society at large [23]. In order to understand these socially embedded actions by Chinese employers and their employees we turn to the concept of the 'moral economy' [40]. Scott examined how peasants in Southeast Asia cope with the constant threat of natural disasters and famine. He refers to a subsistence ethic, whereby the economic relations amongst peasants and between landowners and peasants are characterised by risk avoidance and the sharing of land and labour. This practice of sharing was not based on a romantic idea of equality, but as a means of surviving. Scott defines a subsistence ethic as a moral economy, a social arrangement where human behaviour is guided by risk aversion, standards of reciprocity and ideas about justice (cf. [33], p. 401). Where Scott paid little attention to legal norms, it is clear that the social arrangements within specific communities are also shaped in interaction with these legal norms and the accompanying perceived risks of apprehensions, fines and other possible economic or social costs (cf. [30]).

\section{Chinese migration and the Chinese catering sector}

Similar to other Western European countries, the history of Chinese migration and the emergence of the Chinese catering sector in the Netherlands are closely intertwined [35, 54]. The first Chinese immigrants in the Netherlands arrived in the early 1900s as sailors in the Dutch merchant fleet. Small businesses emerged to cater to the demand for Chinese cuisine of these sailors. After the Second World War Dutch-Indonesians, ex-military personnel and repatriates from Indonesia arrived in the Netherlands which again increased the demand for south-east Asian food as these returnees craved after food they had become accustomed to in Indonesia. The success of the Chinese catering

\footnotetext{
6 'Snakehead' is a Chinese term for human smuggler [59].
} 
sector triggered chain migration and family reunification. Between 1970 and 2000 the number of Chinese restaurants in the Chinese catering sector increased rapidly and accordingly the demand for Chinese restaurant personnel. Chinese immigrants could easily find employment in Chinese restaurants in the Netherlands [42, 54].

Today, the Chinese Dutch population counts around 110.000 persons [7, 42]. In 2010 the Chinese catering sector counted for more than 2100 restaurants and it still is the most popular economic sector for Chinese Dutch. Recently the overall number of restaurants is decreasing, among which also the Chinese restaurants [56]. Chinese restaurants, similar to many other small-scale enterprises in other countries, are often family run firms and based on cheap and informal labour [21]. Working days of ten to thirteen hours for six days a week are common in the Chinese restaurants. Competition between catering businesses are furthermore fierce. To cope with this competition Chinese entrepreneurs of the second and following generations started to develop new business strategies to set themselves apart. Whilst in the early day's restaurants in this sector mainly served Chinese-Indonesian food and aimed at the lower price segments, nowadays owners more often specialize in specific regional cuisines, apply different restaurant formulas, and aim at higher price segments [37]. Although most Chinese Dutch are still (self) employed in the Chinese catering sector, the popularity of the Chinese catering sector is seriously diminishing under the second and following generation of Chinese Dutch (cf. [15, 38]). Long working hours, lack of leisure time, and small profits make the sector unattractive to the younger generations who increasingly focus on employment in the business service sector and commercial trade [42].

\section{Chinese entrepreneurship and the meaning of guanxi and mianzi}

In a moral economy, culture - defined as 'the context that makes behaviour and artefacts meaningful' ([34], p. 23) - takes centre stage. In this article, culture will be operationalised into social, symbolic and cultural capital [5]. Social capital is embedded in social relationships and the value of an individual's social capital is partly dependent on the size of the network of connections he or she can effectively mobilise [5]. Social capital is not a 'quiet possession' and demands constant efforts by individuals or the collective to produce social relations that can help to achieve goals in either the short or the long term. In this process, social ties based on kinship, shared origins or work are transformed into a system of obligations, expectations, and favours. An important aspect of social capital is the reciprocal nature of the exchange, which can be more or less balanced, depending on the underlying relationship [39]. Guanxi is the Chinese term for the way in which the various relationships between people are interpreted. Guanxi depends on the personal relationships between people. Guanxi can be used in an instrumentalist way, but building guanxi has more to do with strengthening the personal relationship between two parties than with the goal one party is trying to achieve [57]. Using guanxi is also based on the idea of valuing a long-term relationship between the parties and going beyond immediate goals [43, 58].

The art of guanxi is also known as acquiring mianzi, the Chinese equivalent of symbolic capital. Mianzi refers to 'face', reputation, standing and prestige. When a person is in a position to do someone else a favour, his mianzi will increase. The more mianzi one has, the easier it gets to build guanxi [43, 58]. Guanxi and mianzi are vital to 
understand how Chinese are able to raise starting capital for their business, attract customers, recruit employees or find employment themselves [10, 36].

Cultural capital, finally, consists of the knowledge a person has acquired and the opportunities this knowledge brings with it. Cultural capital can be accumulated by studying, taking courses or is learned on the job. Forms of cultural capital relevant to operating within a Chinese restaurant are for example the knowledge and skills that are necessary to prepare Chinese dishes and knowledge of the codes of conduct governing the relationship between employer and employee in a Chinese restaurant: the work ethic $[10,36]$.

\section{Research methods, research group and the Chinese restaurants}

The empirical findings discussed in this article rely on long-term ongoing ethnographic fieldwork in four research projects starting in 2009 with a project on labour relations in the Chinese catering sector [19]; the livelihood of undocumented youngsters [46]; the access to healthcare for undocumented migrants ([48, 49]- ongoing); and comparative research on labour relations within Chinese ethnic niches in the Netherlands and Romania in the legal context of labour exploitation ([19]- ongoing). The major part of the data for this contribution was gathered during 2009-2010 where in the context of the first two research projects next to the ethnographic fieldwork among Chinese restaurant owners, semi-structured interviews with twelve Chinese restaurant owners and fourteen current and former employees of Chinese restaurants were carried out. The respondents came from China, Malaysia and Singapore. The fourteen current and former employees consisted of five men and nine women and their ages range from 19 to 38. From these fourteen, twelve respondents were living in the Netherlands without valid residence papers; seven arrived as unaccompanied minors. The restaurant owners were aged between 41 and 65, with the exception of a young restaurant owner, who was 24 . The group of restaurant owners consisted of nine men and three women, ten of whom could be classified as first-generation migrants. Hiah, daughter of an ethnically Chinese restaurant owner, made contact with the restaurant owners and five undocumented Chinese migrants who had not applied for asylum in the past through her personal network and the snowball method. The contact with the Chinese former undocumented unaccompanied minors was made through nongovernmental organisations (NGOs) as refugee shelters. The selection of respondents was based on their professional background and on convenience given the closed character of Chinese communities.

Hiah speaks Teochew and Mandarin and carried out the participant observation and almost all interviews herself. During two interviews she was supported by another respondent who stepped in as an interpreter. During the ethnographic research fieldwork notes were taken and also the majority of the interviews were written up as summaries based on notes taken during the interviews. The data was analysed by thematic as well as open coding strategies, and pattern analysis by using qualitative data analysis software ATLAS.ti.

The Chinese restaurant owners were reluctant to discuss the topic of undocumented immigrants working in their businesses. They were aware of the fact that they could be fined for employing undocumented immigrants and some pointed to possible reputation 
damage. In order to set the restaurant owners at ease, the interviews started with general questions on the employer's views on illegal migrant labour before moving on to their personal experiences. The subject was often discussed in the past tense. Data was also gathered before or after the formal interviews. The undocumented immigrants who worked or were still working in the Chinese restaurants were also careful to discuss their labour because out of solidarity toward their employer, or out of distrust due to the fear of getting arrested and deported. Names of respondents used in this article are fictive to protect the privacy of respondents involved.

Eight of the twelve Chinese restaurant owners in this study owned a small family business with a limited number of employees. These were modest Chinese restaurants and one cafeteria, whose owners were working full-time with their children pitching in whenever needed. Four restaurant owners run somewhat larger establishments which employed ten to a maximum of fifteen employees during peak hours. The total number of employees in these ten establishments is estimated around 75 persons. In the smaller businesses, most of the employees were close relatives. In the four larger businesses with ten to fifteen employees, almost all employees were family members and/or Chinese. Only three of the employees were Dutch. They were friends of the restaurant owner's children who had been hired to serve tables and wash dishes.

Among the estimated 70 to 75 Chinese employers and employees there are bound to be some undocumented Chinese workers, but their exact numbers are unknown as the restaurant owners prefer to remain implicit about these sensitive issues. Restaurant owner Lau was the only one to state that there were four undocumented Chinese employees currently working in his kitchen. He knew for sure that many (large) Chinese restaurants were doing the same. Six other restaurant owners openly admitted that they employed undocumented Chinese in the (recent) past. Mrs Yun told us that she had been forced to temporarily close down her restaurant several years ago after being fined 40,000 euros for employing undocumented Chinese cooks. She told us that she was no longer employing undocumented Chinese workers out of fear for being closed down permanently. Mr Pang, the owner of a large restaurant who only spoke about undocumented workers in the past tense during the interview, was known for employing undocumented cooks in his kitchen. Nine of the fourteen undocumented Chinese immigrants we interviewed were working or had work experiences in Chinese restaurants. The majority of the Chinese former unaccompanied minor asylum seekers were dependent on the support of NGOs.

\section{Labour relations in the Chinese restaurants}

The overall absence of non-Chinese working in the restaurants covered by this study is consistent with the explicit preference of the interviewed restaurants owners for coethnics (cf. [8, 17]). We explain the preference of Chinese entrepreneurs for co-ethnic employees by market considerations as well as by biographical and cultural factors.

\section{Market considerations}

Working hours in the restaurants included in this study ranged from ten to thirteen hours a day, six days a week. Wages are paid on a monthly basis or per day. There are 
generally no hourly wages, not even for part-timers. The Chinese employers tried to reduce labour costs by unpaid family labour, by cutting back on the wages of their regular employees, and by hiring undocumented migrants. Due to the informal employment agreement with undocumented migrants, these workers have no recourse to laws or regulations, which increases their vulnerability and risks of bad working conditions. Undocumented employees are also paid less. The respondents earned an average amount of 800 to 900 euros per month, including board and lodging. Several Dutch studies among Chinese restaurant owners describe similar employment strategies pointing amongst others to the fact that these entrepreneurs tend to neglect labour costs while setting their prices in the business ([24]; cf. [55]). Others as Kwok [26], who did extensive research within the Chinese economy in Vienna, Austria, also describe the preference of co-ethnics among Chinese. They conclude that for some entrepreneurs informal labour is essential in surviving whilst others make huge profits out of it.

According to some restaurant owners, the absence of non-Chinese within Chinese firms is also the outcome of the fact that Chinese employers are unsuccessful in finding suitable and qualified non-Chinese employees through the formal labour recruitment channels [3]. Others however argue that for some restaurant owners it would not come to their minds to search for non-Chinese. Sung, a sixty years old restaurant owner, for instance expresses this by stating that 'the number of employees to choose from, by which I mean legal Chinese workers in the Netherlands, is limited'. In his eyes, the choice for an undocumented Chinese worker is primarily determined by the insufficient supply of suitable legal Chinese workers. Sung did not even mention nor thought of non-Chinese citizens as potential employees. This supply is further limited by the fact that second-generation Dutch Chinese are better educated and increasingly less inclined to pursue a career in the Chinese catering industry (see also [42]).

\section{Overlapping and familiar personal biographies}

The restaurant owners often point to factors relating to their own personal history when explaining illegal migrant labour. Most employers refer to their own undocumented stay and illegal labour in the Chinese catering industry as important elements in their personal migration history. Social networks and the guanxi that they contain are as important to current newcomers as they were during the settlement of the first-generation restaurant owners (see also [45]). An example is Chow (58 years old), who has lived in the Netherlands since 1974. He left his native Malaysia as he was unable to find work there. His friends helped him to raise money for the trip and the 800 ringgit (198 euros) plane ticket. They all flew together to Paris, where they stayed overnight before taking a train to the Netherlands. After a short illegal stay (during which he also worked in a Chinese restaurant), Chow got a residence permit and started working in the kitchens of various Chinese restaurants. He now has his own restaurant for a number of years.

The majority of first-generation entrepreneurs have experiences with staying in the Netherlands without valid residence permits while working in the Chinese catering industry. The length of their undocumented stay ranged from three months to ten years. Yesterday's undocumented workers have become today's restaurant owners and are now in a position to employ their own undocumented Chinese workers. Although Chinese employers are aware that it has become increasingly difficult to become legalized as an undocumented migrant in many West European countries, they still 
perceive undocumented stay as a strategy to attain upward social mobility by arguing that undocumented migrants can earn a living and sent remittances to their families abroad (Cf. [26]). The Chinese community in the Netherlands is so closely intertwined with the Chinese catering industry that undocumented Chinese newcomers through the support of kin or friends easily end up working in this ethnic niche (cf. [31, 47]).

\section{Cultural meanings}

The preference of Chinese restaurant owners for co-ethnics in their businesses is also strongly related to the importance attached by the employers and employees to a shared cultural understanding. Employers refer for instance to the knowledge needed for the right preparation of Chinese dishes (see also [3, 32]). In the words of Mrs Yun: 'Chinese food is different from Dutch food. It's harder to prepare. Dim sum, for instance, is made by hand'. Another reason for the absence of non-Chinese in the Chinese restaurants is made by the employers insisting on employees who speak 'the Chinese language'. Mrs Yun: 'Dutch people don't speak Chinese and my husband has only ever worked in a kitchen, so he doesn't speak Dutch.' Like Mr and Mrs Yun, many restaurant owners are first-generation immigrants with a poor command of the Dutch language. Most employers also prefer employees who can speak more than one dialect, because many restaurants employ workers from different ethnic Chinese groups and not everyone speaks the same language. In addition to their preference for Chinese over non-Chinese employees, the restaurant owners distinguish between Chinese applicants on the basis of region of origin, language group and cultural background [9, 24]. Lau, for instance, tries to compose his kitchen staff in such a way that his employees do not all come from the same background:

'I don't want all the workers that I hire to be from the same region in China. When the people in the kitchen are all from the same region, they will chase away people from other regions. They will take over, and you're no longer the boss.' (Lau, 46 years old, restaurant owner)

Lau takes an instrumental approach to the different cultural backgrounds of ethnic Chinese and the strong guanxi between members of the same subgroup. Other employers, however, prefer employees from their own ethnic background [3, 22, 26].

The 'right' work ethic is also important to employers. As Lee puts it: 'Chinese people work harder than Dutch people.' The restaurant owners expect their workers to put in long hours and long work weeks and - as they see it - Dutch employees are not accustomed to this type of working environment. $\mathrm{Xu}$, the owner of a snack bar, prefers hiring Chinese students over indigenous students. 'The Dutch go to the disco', he says. 'On weekend days, they want to leave early and go out for the night.' This is why Xu prefers Chinese students, who are willing to work until late. In addition, the work ethic of undocumented Chinese immigrants is reason for Chinese restaurant owners to allow them a job:

'Illegal workers work much harder than legal workers. They really want to work.

Legal Chinese have this mentality. When their shift is over, they'll stop working.

Whereas an illegal Chinese worker, a good one, will always finish his job before 
he goes home. Illegal Chinese work harder than legal Chinese.' (Sung, 60 years old, restaurant owner)

Many regular Chinese employees whilst already working longer hours than a regular nine to five job, are reluctant to work overtime, and they know how to access social security benefits when they need to. This is what Chow referred to when he mentioned the costs related to hiring regular Chinese employees. Such employees are not only more expensive, but there is also a risk that they will claim paid sick leave under the Sickness Benefits Act. This is a risk that many Chinese entrepreneurs running smallscale family businesses are unwilling to take.

\section{Contours of a moral economy}

Following Scott [40] we define a moral economy as a subsistence ethic and as a social arrangement where human behaviour is guided by risk aversion, standards of reciprocity and ideas about justice. Within this moral economy it are informal obligations and expectations between employers and employees within the Chinese communities that interact amongst others with the formal obligations or laws and rules defined by the government. Chinese employers as well as Chinese employees are very much aware of the formal rules related to illegal migrant labour, undocumented stay and human trafficking. At the same time there are different sets of informal expectations and obligations within this ethnic economy and of course, there is always a business to run. It is within this interaction between the formal rules given through administrative fines as well as criminal sanctions and the informal obligations Chinese have towards each other that the moral economy of the Chinese catering sector becomes visible.

\section{Risk of incurring fines}

As mentioned above, it is not unusual for a cook in a Chinese restaurant to work six days a week, ten to thirteen hours a day. These working hours apply to both cooks with and without a legal residence status. The main difference is in the wages they are being paid. Undocumented Chinese workers are usually aware of the fact that they are being paid less than co-workers with a residence permit and take this state of affairs for granted.

When we asked the restaurant owners why there was a discrepancy between the wages of regular and undocumented cooks, they pointed to the risk of incurring fines from the Inspectorate $\mathrm{SZW}^{7}$ for employing undocumented migrants. Although the risks of incurring administrative fines have increased after 2000 as a result of the intensified supervision of specific economic branches as the catering industry ([18], pp. 65-77), it did not stop all restaurant owners in this study from hiring undocumented workers. Take for example restaurant owner Lau. In Lau's restaurant, undocumented employees are paid considerably less than regular employees for the same workload. Lau explains

\footnotetext{
7 The Inspectorate SZW of the Ministry of Social Affairs and Employment inspects working conditions and socio-economic security at work (Inspectorate SZW [20]).
} 
that whilst he would gain financial advantage by employing undocumented immigrants, he would at the same time risk an administrative fine. Additionally, to cope with incurred fines, Lau even hinted at the option of deducting future fines from the wages of his undocumented employees. Lau furthermore explains how due to the increased supervision on employing undocumented migrants the wages of undocumented migrants in the Chinese catering sector have dropped:

'In the past, undocumented workers were paid more, because their wages did not include taxes or premiums. These days, it's the other way around. When you employ an illegal worker, you're running a risk (...) Illegal workers are paid 1000 euro [per month] less. Sometimes that is unfair, because they are all good workers. But we don't do it out of choice. It's also about profit margins. When we start paying our workers a lot more, our margins go down.' (Lau, 46 years old, restaurant owner)

Restaurant owners such as Yun on the other hand - who had previously been fined for employing undocumented immigrants - told us that they no longer hired undocumented immigrants because of these fines and the risk of being forced to close their businesses. The differences in wages between legal and undocumented immigrant workers were estimated by Mr. Sung at 20 to $30 \%$. These were also the margins he himself used to apply in the past. When we asked Sung whether or not he thought it was unjust to pay undocumented employees that much less, he answered:

'I try to do what I think is right, and sometimes I give them a little extra money if they work hard, but I can't do that all the time. If I did, other restaurant owners would come and ask me why I'm doing that and that's not good for business. Let me explain. The Chinese community is a closed circle. Everything stays within this circle. A rule has emerged that illegal workers are paid less than legal workers. I don't know why that is so, but if I paid them more, I would upset other restaurant owners and that's not what I want.' (Sung, 60 years old, restaurant owner)

It is obvious that the opinions of other Chinese restaurant owners play an important role in Sung's considerations, which illustrates the social embeddedness of these entrepreneurs $[22,26]$. Sung is part of a social network within the Chinese catering industry and within this network he makes use of his various contacts and the benefits they provide. But this also means that if he wants to maintain his position in the network, he'd better not ruffle the feathers of the other restaurant owners.

Undocumented migrants also referred to the risks their employers took by hiring them. In some cases their previous informal contracts were terminated due to an employer who was no longer willing to take the risk. Several cooks were incarcerated in aliens' detention for performing illegal labour after a check-up by the Inspectorate SZW. Yixin, one of the undocumented cooks, had several experiences with the controls of the Inspectorate SZW. According to Yixin 'in every restaurant you can find illegals [and] every month they will check for undocumented employment once' but he always managed to run away in time. Although he was never detained, he had to change jobs regularly as his employers became afraid for the many check-ups by the Inspectorate. 


\section{Informal obligations and expectations}

Informal obligations and expectations between employers and employees are manifold. Undocumented immigrants may know to be paid less but they also expect other nonfinancial gains from their employers. One important expectation is the norm for employers of providing work and accommodation as a package to the employee. The undocumented Chinese workers we interviewed all pointed to this implicitly assumed combination of work and accommodation. Dao, an undocumented 29 years old, Chinese migrant who is currently unemployed: 'Apart from my salary, I was also given board and lodging, but that's normal in the Chinese catering industry. Legal employees get the same.' Restaurant owners with businesses in remote areas often have a difficult time finding employees. Regular employees with a house and a family are generally unwilling to move to a small village, but such a move is much easier for undocumented immigrants without a family or a fixed place of residence. This makes it all the more important for the employer to be able to offer accommodation (cf. [24], p. 89). The expectation or informal obligation to offer work with housing also refers to the generally flexible approach to the separation of work and private life in Asian businesses (cf. [12]). The informal and personal relationship between employer and employee in Chinese restaurants plays an important role, which tends to blur the line between work and the private sphere in managing the business. As mentioned earlier, guanxi refers to personal bonds between people and this also applies to employers and their employees.

Within the Chinese catering industry board and lodging is considered more as logical gesture to the employees and not as a strategy to make the employee more depended on the employer whilst in the criteria formulated by the Dutch Supreme Court offering housing next to employment is considered as multiple dependency (Dutch Supreme Court, 27 October [13], LJNBI7079).

\section{Second generation}

When we brought up the subject of labour exploitation, opinions among the restaurant owners were divided. Sung is convinced that the new generation of restaurant owners is mostly to blame and because the character of Chinese restaurants has changed and traditional relations have lost their meaning:

'This is the new generation. They offer some kind of fast food Chinese. The number of employees has only gone down. That's because the second generation doesn't want to work in the sector. This will make [exploitation] more prevalent.' (Sung, 60 years old, restaurant owner)

Sung's complaint about the second generation is in line with the sketched development in the literature that second generation Dutch Chinese who are increasingly higher educated, seek employment outside the Chinese catering sector [42]. Whilst this development means that the Dutch Chinese are upward social mobile, it has consequences for those who are 'left behind' in the Chinese restaurants.

Restaurant owners are aware of the formal rules around labour exploitation but in many cases disagree with the images surrounding exploitation. According to restaurant 
owner Pang exploitation is not a neutral term and to support his claim, he gives the example of children working in their parents' businesses:

'Children are also often exploited [when they're not being paid]. As Chinese, we would say that they're only helping their parents, but the Dutch would call it exploitation.' (Pang, 51 years old, restaurant owner)

\section{Dutch stereotypes surrounding exploitation}

Pang calls attention to the differences in how Dutch Chinese and indigenous Dutch consider and assess labour relations in the Chinese catering industry. Restaurant owners also distance themselves from Dutch stereotypes surrounding labour exploitation in which the employers are perceived as 'criminals' and the undocumented immigrants as 'vulnerable victims'. Restaurant owner Chow is critical of the idea that restaurant owners are exploiting their employees:

'Chinese people are afraid to exploit anyone; they're the ones being exploited. They're being threatened with weapons. They get threats from illegal migrants, who organise themselves and start to exploit entrepreneurs by threatening them (...) Yes, these people [employees earning 200 euros a month] are really stupid, who would accept that? I don't buy it. As soon as they [undocumented Chinese migrants] get arrested, they'll tell the authorities that they're being exploited in order to gain sympathy and a residence permit. It's all bogus. Everything you see on television is fake. All these people want is a residence permit. Thirty-year-olds will claim to be no older than twenty.' (Chow, 58 years old, restaurant owner)

The practices described by Chow are not just isolated instances (cf. [2]). Xu mentioned an incident whereby his brother-in-law was intimidated by a former undocumented employee who had developed a grudge against him because he was fired after months of work for too little pay. During our fieldwork we came across several stories about undocumented workers who had threatened to report their employers to the 'authorities' for treating them badly or refusing to employ them any longer. The Chinese undocumented immigrants accept low payments and bad working conditions to a certain degree, if it is not below a certain level and if other expectations as housing and care are met. Employers gain guanxi as long as they adhere to these informal obligations towards the undocumented immigrants as well as towards other employers. What these incidents demonstrate is that, when these informal obligations are ignored and reciprocal expectations within the Chinese catering industry's 'arrangements' are not met, the Chinese undocumented immigrants are willing to take a stand against their employers. In doing so these undocumented immigrants reaffirm the borders of the moral economy within the Chinese community and reverse the offender-victim perspective (cf. [41], p. 28-37). Such instances of strained relations, whereby undocumented immigrants stand up and take a stand against their employers, demonstrate that perceiving undocumented immigrants solely in terms of vulnerability, denies their human agency by which they can secure some justice within their social arrangement. 
Additionally these stories also point to the mutual dependencies that exist between employers and employees as to working within a moral economy in which formal social control competes with informal control. Chinese undocumented employees depend on their employers for (informal) work, but restaurant owners also depend on the cooperation of their undocumented employees so they can keep their business running and economically advantageous (See [26]). Within the moral economy of the Chinese catering sector formal control is always present. For the undocumented this means that they continuously have to face the risk of being apprehended and being deported. The employers face possible administrative fines and ultimately the closing down of their business or could even be accused of human trafficking under specific circumstances.

The different social interactions between Chinese employers and employees within the Chinese catering sector all illustrate how these labour relations are influenced by different means of informal as well as formal control from administrative as well as criminal law. As an immediate result of these (increased) forms of administrative as well as criminal control, the socio-economic position of the undocumented immigrants become more precarious due to worsened labour conditions and decreasing job security. The informal labour market for all undocumented immigrants has deteriorated as a consequence of increased supervision and tougher control measures by the Dutch government. Undocumented immigrants increasingly have to rely on support of country fellowmen or charity where supportive ethnic communities are unavailable. At the same time the number of undocumented immigrants that is apprehended for crime is increasing [27, 46]. The increased governmental control measures also has consequences for the Chinese employers as they develop different strategies to keep their businesses competitive enough to survive and to be profitable.

Finally, despite several efforts to attract and train indigenous Dutch for vacancies in the Chinese restaurants, the (licit) staff shortages in the Chinese catering sector have to this day not been solved. There is a lack of interest from indigenous Dutch to work in the Chinese restaurants and simultaneously stakeholders of the Chinese catering sector encountered difficulties in organizing a suitable course programme in combination with trainee posts in the Chinese restaurants [11]. The agreement between the Dutch government and stakeholders of the Chinese catering sector will however only be applicable until September 2016.

\section{Discussion}

Chinese cuisine stands for tasty and affordable food. Behind the inexpensive 'sweet and sour pork' lies a moral economy where labour relations are determined through market mechanisms of demand and supply, formal rules, regulations and controls, as well as by informal obligations and expectations that are embedded in social arrangements and shaped by cultural meanings of guanxi. It is also a moral economy in which specific labour practices increasingly conflict with the Dutch Government's efforts to control immigration. Administrative measures such as the amendment of the WAV and jurisprudence that has broadened the reach of article 273 f on human trafficking in the Dutch Criminal Code aim to further restrict the access of immigrants to the Netherlands and to further exclude undocumented immigrants after arrival. 
During the last decade the enforcement of the WAV has been transformed from criminal law to administrative law. The prohibition of illegal migrant labour within a specific economic sector as the Chinese catering can be much more easily enforced through controls and fines than through complex, time consuming and inefficient criminal procedures. The analyses of the moral economy of the Chinese catering sector in the Netherlands illustrate how the effects of administrative law and the (threat of) criminal law in the Chinese restaurants weakens the socio-economic position of undocumented immigrants and threatens the livelihood of these restaurant owners. The current definition of crimmigration falls short in this case as it is not only criminal law, but much more the combination of crime control, administrative control and migration control that merge.

It has become clear that these measures have implications for labour practices within the Chinese catering industry. We have described how the amendment of the WAV has made it near to impossible for Chinese restaurant owners to hire Chinese cooks from China through formal channels and at the same time, the increased supervision on employing undocumented immigrants has made Chinese restaurant owners more reluctant to employ them in their businesses. Simultaneously, in order to continue their business, Chinese employers feel dependent on Chinese employees with a specific work ethic. The restaurant owners find these expectations met among co-ethnics and especially among the undocumented co-ethnics. Some restaurant owners have ceased to employ undocumented immigrants. Others that do keep employing them, lower employees' wages and/or some even hint to deduct possible fines from salaries of their undocumented immigrant personnel.

For the undocumented Chinese migrants the increasing control through administrative and criminal law means that it has become more difficult for them to survive through informal work and when they do find employment, the labour conditions under which they are working have worsened. Furthermore, where employers increasingly run the risk of receiving administrative fines for illegal employment, they also run the risk of prosecution under criminal law for exploiting legal or undocumented workers under poor working conditions in combination with underpayment and/or creating multiple dependency through providing accommodation or other services.

Formal rules interact with informal obligations and dependencies between employers and employees within the Chinese moral economy. Employers as well as undocumented employees know that the latter will be paid less but can also expect other non-financial gains as lodging and housing from their employers. Seen from a Chinese perspective this arrangement is perceived as an informal obligation, where for the Dutch Supreme Court it is major evidence for human trafficking as was argued in the 'Chinese Catering Sector' case.

Within the discourse of human trafficking and labour exploitation employers are turned into offenders and employees into victims. These legal categories poorly reflect the meanings employers and employees themselves attach to their behaviours and feelings of justice. Above all, taking an overly one-sided legal perspective on labour exploitation, makes it impossible to obtain a clear picture of the underlying causes of illegal stay and illegal migrant labour, which are connected to policy changes regarding work performed by immigrants, a demand for cheap products, and perceptions of qualified, flexible, and highly motivated labour that Dutch citizens are either unwilling or unable to satisfy. 
Open Access This article is distributed under the terms of the Creative Commons Attribution 4.0 International License (http://creativecommons.org/licenses/by/4.0/), which permits unrestricted use, distribution, and reproduction in any medium, provided you give appropriate credit to the original author(s) and the source, provide a link to the Creative Commons license, and indicate if changes were made.

\section{References}

1. Aas, K. F. (2011). 'Crimmigrant' bodies and bona fide travelers: surveillance, citizenship and global governance. Theoretical Criminology, 15(3), 331-346.

2. Blaak, M., Engelhard, D., De Frenne, F., \& Sproet, M. (2004). De smaak van noedelsoep. Begeleiding van Chinese AMA's in opvang en onderwijs. Utrecht: Pharos.

3. Bloch, A., \& McKay, S. (2015). Employment, social networks and undocumented migrants: the employer perspective. Sociology, 49(1), 38-55.

4. Bogaerts, A., De Jonge van Ellemeet, H., \& Van der Leun, J. (2009). Slavernijachtige uitbuiting in Nederland en de rol van cultuur. Proces, 88(5), 263-275.

5. Bourdieu, P. (1986). The forms of capital. In J. Richardson (Ed.), Handbook of theory and research for the sociology of education (pp. 241-258). New York: Greenwood.

6. Bulletin of Acts and Decrees. (2013). Law of 2013 November 25th. The Amendment of the Foreign Nationals Employment Act, Bulletin of Acts and Decrees, 2013, 499. (vertaald van : Wet van 25 november 2013 inzake herziening van de Wet arbeid vreemdelingen, Stb, 2013, 499.)

7. CBS. (2015). CBS Statline. Bevolking; generatie, geslacht, leeftijd en herkomstgroepering, 1 januari. [Data set]. Retrieved from http://statline.cbs.nl/Statweb/publication/?DM=SLNL\&PA=37325\&D1=a\&D2=a\&D3=0 $\& D 4=a \& D 5=46,90,223 \& D 6=1 \& V W=T$.

8. Ceccagno, A., Rastrelli, R., \& Salvati, A. (2010). Exploitation of Chinese immigrants in Italy. In Y. Gao (Ed.), Concealed chains. Labour exploitation and Chinese migrants in Europe (pp. 89-138). Geneva: ILO.

9. Chong, Y. (2005). De Chinezen aan de Binnen Bantammerstraat. Amsterdam: Het Spinhuis.

10. De Assunção Raposo Rodrigues, I. (2012). Flows of fortune: the economy of Chinese migration to Portugal. Dissertation, Universidade de Lisboa.

11. De Lange, T. (2014). Kroniek Arbeidsmigratie. Asiel \& Migrantenrecht, 8-9, 358-365.

12. Dicken, P. (2007). Global shift. Mapping the changing contours of the world economy. London: Sage.

13. Dutch Supreme Court. (2009), LJNBI7079 (Chinese Catering Sector Case).

14. Dutch Supreme Court. (2002), NJ 2002/546 (Trafficking case).

15. Engelen, E. (2010). Etnisch ondernemerschap 2.0. Tijdschrift voor Sociale Vraagstukken, 64(12), 19-23.

16. Esser, L., \& Dettmeijer-Vermeulen, C. (2014). Mensenhandel op een tweesprong. De omgang van rechters met de ruim geformuleerde mensenhandelgedraging in de delictsomschrijving van artikel $273 \mathrm{flid} 1 \mathrm{sub} 4 \mathrm{Sr}$. Delikt en Delinkwent, 48(7), 512-528.

17. Gao, Y., \& Poisson, V. (2010). Exploitation of Chinese immigrants' vulnerabilities in France. In Y. Gao (Ed.), Concealed chains. Labour exploitation and Chinese migrants in Europe (pp. 33-88). Geneva: ILO.

18. Grandiek, M. (2015). De rijen gesloten houden. Onderzoek naar de methoden van bestrijding van arbeidsuitbuiting van vreemdelingen en de benadering van vreemdelingen in de context van crimmigratie. Rotterdam: Erasmus Universiteit Rotterdam (master thesis Criminology).

19. Hiah, J. (2010). Door de ogen van de baas. Chinese werkgevers en werknemers over [illegale] arbeid en uitbuiting in de Chinese Horeca. Rotterdam: Erasmus Universiteit Rotterdam (master thesis Criminology).

20. Inspectorate SZW (2013). What does the Inspectorate SZW do? http://www.inspectieszw.nl/english/index.aspx. Accessed 4 June 2016.

21. Jones, T., Ram, M., \& Edwards, P. (2006). Shades of grey in the informal economy. International Journal of Sociology and Social Policy, 26(9-10), 357-373.

22. Katila, S., \& Wahlbeck, Ö. (2012). The role of (transnational) social capital in the start-up processes of immigrant businesses: the case of Chinese and Turkish restaurant businesses in Finland. International Small Business Journal, 30(3), 294-309.

23. Kloosterman, R., Van der Leun, J., \& Rath, J. (1999). Mixed embeddedness: (in)formal economic activities and immigrant businesses in the Netherlands. International Journal of Urban and Regional Research, 23(2), 253-267.

24. Knotter, J., Korf, D., \& Lau, H. (2009). Slangenkoppen en tijgerjagers. Illegaliteit en criminaliteit onder Chinezen in Nederland. Den Haag: Boom Juridische uitgevers.

25. Krop, P. (2014). De handhaving van het verbod op illegale tewerkstelling. De verhouding tussen strafrechtelijke en bestuursrechtelijke handhaving in de Werkgeverssanctierichtlijn, Nederland en Duitsland. Den Haag: Boom Juridische uitgevers. 
26. Kwok, K. (2012). Chinese immigrant economy in Vienna in transnational era. Dissertation, Universität Wien. http://othes.univie.ac.at/21064/1/2012-05-23_9507535.pdf.

27. Leerkes, A. (2009). Illegal residence and public safety in the Netherlands. Amsterdam: Amsterdam University Press.

28. Lestrade, S., \& Rijken, C. (2014). Mensenhandel en uitbuiting nader bepaald. Delikt en Delinkwent, 64(9), 655-681.

29. Lestrade, S., \& Ten Kate, W. (2009). De strafbaarstelling van 'overige uitbuiting' binnen mensenhandel. Nederlands Juristen comité voor de mensenrechten bulletin, 34(8), 852-870.

30. Moore, S. F. (1973). Law and social change: the semi-autonomous social field as an appropriate subject of study. Law \& Society Review, 7(4), 719-746.

31. Mustafa, M., \& Chen, S. (2010). The strength of family networks in transnational immigrant entrepreneurship. Thunderbird International Business Review, 52(2), 97-106.

32. Nakhaie, R., Lin, X. H., \& Guan, J. (2009). Social capital and the myth of minority self-employment: evidence from Canada. Journal of Ethnic and Migration Studies, 35(4), 625-644. doi:10.1080/13691830902765244.

33. Näre, L. (2011). The moral economy of domestic and care labour: migrant workers in Naples, Italy. Sociology, 45(3), 396-412. doi:10.1177/0038038511399626.

34. Oude Breuil, B. (2011). Alles stroomt...? Over 'cultuur' in de culturele criminologie. Tijdschrift over Cultuur \& Criminaliteit, 1, 18-34.

35. Pang, C. (2002). Business opportunity or food pornography? International Journal of Entrepreneurial Behavior \& Research, 8(1-2), 148-161.

36. Pieke, F., Nyíri, P., Thunø, M., \& Ceccagno, A. (2004). Transnational Chinese. Fujianese migrants in Europe. Stanford: Stanford University Press.

37. Rijkschroeff, B., Chung, W., \& Zhang, X. (2011). Honderd jaar Chinezen in Nederland. Den Haag: OnsBos.

38. Rusinovic, K. (2006). Dynamic entrepreneurship. First and second-generation immigrant entrepreneurs in Dutch cities. Amsterdam: Amsterdam University Press.

39. Sahlins, M. D. (1974). Stone age economics. New York: Aldine de Gruyter.

40. Scott, J. (1976). The moral economy of the peasant. Harvard: Harvard University Press.

41. Scott, J. (1985). Weapons of the weak. Everyday forms of peasant resistance. New Haven and London: Yale University Press.

42. SCP. (2011). Chinese Nederlanders: van horeca naar hogeschool. Den Haag: Sociaal Cultureel Planbureau.

43. Smart, A. (1993). Gifts, bribes and guanxi: a reconsideration of Bourdieu's social capital. Cultural Anthropology, 8(3), 388-408.

44. Smit, M. (2011). Trafficking in human beings for labour exploitation. The case of the Netherlands. Trends in Organized Crime, 14(2-3), 184-197.

45. Soudijn, M. (2006). Chinese human smuggling in transit. Den Haag: Boom Juridische uitgevers.

46. Staring, R., \& Aarts, J. (2010). Jong en illegaal in Nederland. Een beschrijvende studie naar de komst en het verblijf van onrechtmatig verblijvende (voormalige) alleenstaande minderjarige vreemdelingen en hun visie op de toekomst. Den Haag: Boom Juridische uitgevers.

47. Staring, R. (2004). Facilitating the arrival of illegal immigrants in the Netherlands: irregular chain migration versus smuggling chains. Journal of International Migration and Integration, 5(3), 273-294.

48. Staring, R. (2012). Moderne slavernij of gewoon werk? Den Haag: Boom Juridische uitgevers.

49. Staring, R. (2012). Crimmigratie en de morele economie van illegale vreemdelingen. Proces, 91(6), 396-407.

50. Stumpf, J. (2006). The crimmigration crisis: immigrants, crime and sovereign power. American University Law Review, 56(2), 367-420.

51. Turner, J., \& Kelly, L. (2009). Trade secrets. Intersections between diasporas and crime groups in the constitution of the human trafficking chain. British Journal of Criminology, 49(2), 184-201.

52. Van der Leun, J., \& Kloosterman, R. (2006). Going underground: immigration policy changes and shifts in modes of provision of undocumented immigrants in the Netherlands. Tijdschrift voor Economische en Sociale Geografie, 97(1), 59-68. doi:10.1111/j.1467-9663.2006.00496.x.

53. Van der Leun, J. (2010). Crimmigratie. Apeldoorn: Maklu.

54. Van Eijl, C. (2012). Tussenland: illegaal in Nederland, 1945-2000. Hilversum: Verloren.

55. Vogels, R., Geense, P., \& Martens, E. (1999). De maatschappelijke positie van Chinezen in Nederland. Assen: Van Gorcum.

56. Wagenvoort, H. (2015). Daling aantal restaurants zet door. http://www.missethoreca.nl/restaurant/nieuws/2015 /4/daling-aantal-restaurants-zet-door-101197434. Accessed 15 Apr 2015.

57. Willemse, L. (2014). The role of economic factors and guanxi networks in the success of Chinese shops in Johannesburg, South Africa. Urban Forum, 25(1), 105-123.

58. Zhang, N. (2011). The impact of guanxi networks on the employment relations of rural migrant women in contemporary China. Industrial Relations Journal, 42(6), 580-595.

59. Zhang, S. X. (2008). Chinese human smuggling organizations: families, social networks, and cultural imperatives. Stanford: Stanford University Press. 